P-ISSN: 2774-4574; E-ISSN: 2774-4582

TRILOGI, 2(3), September-Desember 2021 (311-318) @2021 Lembaga Penerbitan, Penelitian, dan Pengabdian kepada Masyarakat (LP3M) Universitas Nurul Jadid Paiton Probolinggo

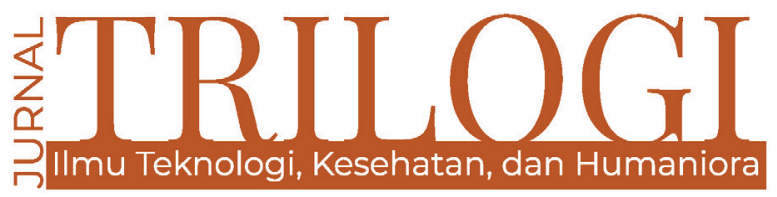

\title{
PENGARUH PERILAKU PERAWAT TERHADAP KEPUASAN KLIEN DI PAVILIUN MASKIN RUMAH SAKIT WALUYO JATI KRAKSAAN PROBOLINGGO
}

\section{Handono Fatkhur Rahman}

Universitas Nurul Jadid, Probolinggo

handono.hfc@gmail.com

\section{Ahmad Kholid Fauzi}

Universitas Nurul Jadid, Probolinggo

kholid0404@gmail.com

Tutik Nurjannah

Universitas Nurul Jadid, Probolinggo

\author{
Raudatul Jannah \\ Universitas Nurul Jadid, Probolinggo \\ Miftahul Jannah \\ Universitas Nurul Jadid, Probolinggo \\ Winda Mardiana \\ Universitas Nurul Jadid, Probolinggo
}

Uud Hulsiyatul Munawaroh

Universitas Nurul Jadid, Probolinggo

\begin{abstract}
Abstrak
Perilaku peduli adalah sikap, rasa peduli, menghargai orang lain. ditingkatkanmutu asuhan keperawatan didukung oleh berkembangnya teori-teori keperawatan, salah satunya adalahteori menurut Jean Watson Caring Behavior, sehingga klien puas denganpelayanan kesehatan. Tujuan dari penelitian ini adalah untuk mengetahui apakah ada Pengaruh PerilakuCaring Perawat Terhadap Tingkat Kepuasan Klien Dalam Asuhan Keperawatan di Ruang Paviliun Maskin RSUD Waluyo Jati Kraksaan Probolinggo. Penelitian ini menggunakan desain analitik korelasionaldengan pendekatan cross sectional. Populasi dalam penelitian ini adalah seluruh perawat yang ada dipaviliun Maskin jumlah responden dan 17 pasien yang dirawat di paviliunLounge Maskin sejumlah 33 responden. Teknik pengambilan sampel yang digunakan dalam sampel penelitian inijumlah perawat menggunakan teknik "Total sampling" dan sampel pasien menggunakan"pengambilan sampel secara purposive". Penelitian dilakukan pada bulan April 2017. Instrumen yang digunakan dalam penelitian iniPenelitian ini berupa kuesioner tingkat kepuasan responden terhadap observasi pasien dan perawatlembar untuk responden. Setelah data terkumpul meliputi pengumpulan data coding, editing dantabulasi, kemudian data dianalisis secara manual dan menggunakan uji
\end{abstract}


statistik komputerWilxocon. Hasil penelitian menunjukkan sebagian besar perawat di ruangan paviliun melamar miskinperilaku peduli perilaku sebanyak 12 responden $(70,6 \%)$, sebagian besar pasien dirawat dipaviliun miskin menyatakan sangat memuaskan sebanyak 27 responden $(81,8 \%)$. BerdasarkanStatistik Uji Wilcoxon menunjukkan bahwa nilai p value sebesar 0,000 dengan tingkat signifikansidari 0,05. Dengan demikian, nilai p lebih kecil dari $(0,05)$ sehingga dapat disimpulkan bahwa $\mathrm{H} 1$ adalahditerima yang artinya ada Pengaruh Perilaku Caring terhadap Tingkat Kepuasan KlienPerawat Dalam Asuhan Keperawatan Di Ruang Paviliun Maskin RS Waluyo Jati KraksaanProbolinggo. Berdasarkan penelitian ini dapat disimpulkan bahwa perilaku caring perawat berpengaruh terhadaptingkat kepuasan klien dalam pelayanan asuhan keperawatan. Dengan menerapkan perilaku caring perawatdiharapkan dapat memberikan pelayanan yang prima kepada klien, sehingga klien merasa aman, nyaman danklien merasa puas dengan pelayanan kesehatan.

Kata kunci: perilaku asuhan keperawatan, kepuasan, asuhan keperawatan

\begin{abstract}
Caring behavior is an attitude, a sense of caring, respect for others. improving the quality of nursing care is supported by the development of nursing theories, one of which is the theory according to Jean Watson Caring Behavior, so that clients are satisfied with health services. The purpose of this study was to determine whether there was an influence of nurse caring behavior on the level of client satisfaction in nursing care in the Maskin Pavilion Room at Waluyo Jati Kraksaan Hospital Probolinggo. This study uses a correlational analytic design with a cross sectional approach. The population in this study were all nurses in the Maskin pavilion with a total of 33 respondents and 17 patients treated in the Maskin Lounge pavilion. The sampling technique used in this research sample was the number of nurses using the "total sampling" technique and the patient sample using "purposive sampling". The study was conducted in April 2017. The instrument used in this study was a questionnaire on the level of respondents' satisfaction with patient observations and sheet nurses for respondents. After the data was collected, it included coding, editing and tabulating data collection, then the data were analyzed manually and using the Wilxocon computer statistical test. The results showed that most of the nurses in the pavilion room applied for poor caring behavior as many as 12 respondents (70.6\%), most of the patients treated in the poor pavilion stated that they were very satisfied with 27 respondents $(81.8 \%)$. Based on the Wilcoxon test statistic, it shows that the $\mathrm{p}$ value is 0.000 with a significance level of 0.05 . Thus, the $\mathrm{p}$ value is smaller than (0.05) so it can be concluded that $\mathrm{H} 1$ is accepted, which means that there is an influence of caring behavior on the level of client satisfaction in nursing care in the Maskin Pavilion Room at Waluyo Jati Kraksaan Hospital, Probolinggo. Based on this research, it can be concluded that the caring behavior of nurses affects the level of client satisfaction in nursing care services. By implementing caring behavior, nurses are expected to provide excellent service to clients, so that clients feel safe, comfortable and clients are satisfied with health services.
\end{abstract}

Keywords: nursing care behavior, satisfaction, nursing care

\section{Pendahuluan}

Mengingat pergeseran demografis, pergeseran sosial ekonomi, serta semakin meningkat dan semakin kompleks masalah kesehatan akan berdampak pada tuntutan dan kebutuhan masyarakat terhadap kesehatan pelayanan termasuk pelayanan keperawatan. Itu masyarakat lebih sadar akan hak dan kewajiban untuk menuntut tersedianya pelayanan kesehatan dan keperawatan dengan kualitas yang bertanggung jawab secara profesional, sehinggatingkat kepuasan masyarakat terhadap kesehatan layanan sangat baik. Menghadapi ini globalisasi tidak ada upaya lain yang perlu dilakukan melakukan penyesuaian dan perbaikan terhadapkualitas pelayanan keperawatan. Kualitas yang ditingkatkan pelayanan keperawatan didukung olehperkembangan teori keperawatan, salah satunya yang merupakan teori Perilaku Pedulimenurut Jean Watson (Potter \& Perry,2005).

Perilaku Peduli adalah sikap, aorang yang peduli, hormat dan hormat, yang berarti memberi lebih banyak perhatian pada seseorang 
dan bagaimana seseorang bertindak. Karena peduliperilaku adalah kombinasi dari perilaku manusia yang bermanfaat dalam meningkatkan derajat kesehatan dimembantu pasien yang sakit. Merawatperilaku sangat penting untuk mengembangkan, memperbaiki, memperbaiki kondisi atau cara kehidupan manusia dan sangat penting dalampelayanan keperawatan karena akan memberikankepuasan kepada klien dan perawatan akan lebih baik memahami konsep kepedulian, terutama melamar dalam pelayanan keperawatan (Potter \& Perry,2005).

Kepuasan klien juga eratberkaitan dengan asuhan keperawatan yang dilakukan oleh perawat.Anjaswarni (2002) tentang hasil karyanyapenelitian menegaskan bahwa secara keseluruhanrata-rata tingkat kepuasan klien yang tinggi padapelayanan kesehatan oleh perawat di RSUD Dr.SaifulAnwar Malang. Berdasarkan rataratapencapaian tingkat kepuasan ini dapatterlihat bahwa tingkat pencapaian klienkepuasan terhadap pelayanan kesehatan sebesar $82,25 \%$ yang berarti klien cenderung merasa puas. Ituhasil studi Ismar tahun 2002 di MuhammadRumah Sakit Hoesin Palembang menunjukkan bahwahampir semua perawat yang belajar di kelas tidakmenerapkan caring $(48,3 \%)$ dalam memberikan asuhan keperawatan perawatan kepada klien.

Ruang paviliun maskin RSUDRS Waluyo Jati Kraksaan adalah pasien rawat inapkamar dengan jumlah klien terbanyakdibandingkan dengan ruang rawat inap lainnya. Daristudi pendahuluan yang dilakukan pada bulan April 2017dilakukan di ruang paviliun pribadi dengan $10 \mathrm{klien}, 70 \%$ mengatakan perawat cenderung kurangramah, judes, sering gak peduliklien, dan 30\% mengatakan perawat ramahdan baik terhadap klien.

Keperawatan adalah bentuk profesional pelayanan yang memiliki paradigma atau model keperawatanyang mencakup empat komponen: manusia, kesehatan,lingkungan dan perawat itu sendiri. Perawat adalahprofesi yang mulia, karena itu membutuhkan kesabarandan tenang dalam melayani pasien yang sedang menderitadari penyakit. Seorang perawat harus mampu melayani pasien dengan sepenuh hati) Sebagai seorang perawat harus mampu memahami masalah yang dihadapi klien, selain itu perawat dapat melihat menarik. Untuk itu seorang perawat membutuhkan kemampuan memperhatikan orang lain, intelektual, keterampilan teknis dan interpersonal tercermin dalam perilaku peduli atau kasih sayang (Dwidiyanti,2007).
Perilaku peduli sangat penting untuk perawatan. Caring adalah fokus pemersatu untuk keperawatan praktek. Perilaku peduli juga sangat penting untuk menumbuhkan bunga, meningkatkan danmemperbaiki kondisi atau cara hidup manusia.Peduli mengandung 3 hal yang tidak bisamemisahkan perhatian, tanggung jawab, dandilakukan dengan keikhlasan. Perilaku peduli jugasikap peduli, menghormati dan Menghargai orang lain berarti memperhatikandan pelajari kegembiraan seseorang dan bagaimana caranyaberpikir dan bertindak. Memberikan kepedulian bukan hanya sekedarperasaan emosional atau perilaku sederhana, karenaCaring adalah kepedulian untuk mencapai asuhan yang lebih baik, perilaku peduli bertujuan dan berfungsi untuk membangunstruktur sosial, pandangan hidup dan nilai budayasetiap orang yang berbeda di satu tempat, makakinerja perawat khususnya pada caringperilaku menjadi sangat penting dalammempengaruhi kualitas pelayanan dan pasienkepuasan, terutama di rumah sakit, di manakualitas pelayanan menjadi penentucitra lembaga pelayanan yang akanmampu meningkatkan kepuasan pasien dankualitas layanan (Potter \& Perry, 2005).

Ilmu keperawatan adalah disiplin yang berkembangsains dan perawat sebagai isu atau profesiditantang untuk lebih tanggap terhadap klienkebutuhan, yang berimplikasi pada kesehatan atausistem perawatan kesehatan. Hal ini sejalan dengantujuan akhir keperawatan, yaitu membantuklien mencapai potensi kesehatan penuh. dalam membantuklien mencapai potensi kesehatan penuh perawatharus memiliki pendekatan menyeluruh.Pendekatan keperawatan yang komprehensif, yaituasuhan keperawatan bio, psiko, sosial, spiritual adalahpendekatan yang digunakan oleh perawat (Potter \& Perry,2005).

Pendekatan ini menggunakan konsep dan pengetahuan yang berkaitan dengan keperawatan salah satunya adalahperilaku peduli. Dengan perilaku peduli perawatmemberikan komitmen dan layanan sebagai pusatperhatian dan inti keperawatan sebagai kemampuanuntuk memahami sikap dan kebutuhan dankeinginan klien. Dalam penerapannya perawat harus mampu memberikan asuhan keperawatanpelayanan kepada individu, keluarga danmasyarakat yang membutuhkan, tanpa membeda-bedakankondisi atau penyakitnya. Sehingga orang merasapuas dengan pelayanan kesehatan yang berkualitas danprofesional (Potter \& Perry, 2005). 


\section{Metode}

Desain yang digunakan dalam penelitian ini adalah "analisis korelasi dengan CrossPendekatan bagian" di mana jenispenelitian yang menekan kandata survei waktu pengukuranvariabel bebas dan terikathanya satu kali pada satu waktu. Penelitian inidilakukan pada bulan April 2017 diruangan Paviliun Maskin Waluyo JatiRSUD Kraksaan Probolinggo.Populasi dalam penelitian ini adalah semuaperawat di ruang Paviliun Maskin17 responden dan pasien sedangdirawat di Space Paviliun Maskin asebanyak 33 responden.Dalam penelitian ini sampel yang diambil oleh semuapara perawat di ruang Paviliun Maskinsebanyak 17 responden dan pasien dirawat di Paviliun MaskinKamar berjumlah 33 responden. Itukriteria inklusi dalam sampel ini adalah: 1) Pasien yang dirawat inap diRuang Paviliun Maskin, 2) Pasienmau belajar, 3) Pasien yang tidakmengalami penyakit serius. Contohmenggunakan semua perawat di ruangan Paviliun Maskin nomor 17responden dan pasien yang sedangdirawat di Space Paviliun Maskin sebagai sebanyak 33 responden, Dalam penelitian inisampel perawat menggunakan teknik"Total sampling" dan sampel pasienmenggunakan teknik "Purposive Sampling".

Variabel bebas dalam penelitian iniadalah Caring Behavior perawat. Variabel tak bebas dalam penelitian ini tingkat kepuasan klien dalampelayanan asuhan keperawatan. Instrumen adalah alat pada saatpenelitian menggunakan metode (Arikunto, 2005). Dipengumpulan data penelitian ini menggunakan surveilembar untuk perawat dan kuesioner yang diberikan kepadapasien.

Kuesioner yang sudah diisioleh responden diberi kode menurut Kriteria ditentukan, didistribusikan, dan dianalisis secara kuantitatif. Data selanjutnya diuji dengananalisis uji statistik "Wilcoxon" menggunakan program media komputer "Windows SPSS17". Kemudian peneliti menyimpulkan hasil penelitian sebagai berikut: "Jika nilai pnilai > dari $=0,05$, maka $\mathrm{HO}$ diterima, artinya tidak ada pengaruh perilaku caring perawat terhadap tingkat kepuasan klien dalam pelayanan asuhan keperawatan. Sebaliknya Jika nilai $\mathrm{p}<$ dari $=0,05$, maka $\mathrm{H} 1$ adalah diterima, artinya ada pengaruh caring perilaku perawat ke level klien kepuasan dalam pelayanan asuhan keperawatan.

\section{Hasil dan Pembahasan}

Tabel 1:

Distribusi frekuensi responden karakteristik berdasarkan Perilaku Peduli perawat di Paviliun Luar Angkasa Maskin RSUD Waluyo Jati Kraksaan Probolinggo, April 2017

\begin{tabular}{ccc}
$\begin{array}{c}\text { Caring } \\
\text { Behavior }\end{array}$ & $\begin{array}{c}\text { Frequency } \\
(\mathbf{F})\end{array}$ & $\begin{array}{c}\text { Precentage } \\
(\%)\end{array}$ \\
\hline Caring & 12 & 70,6 \\
Not Caring & 5 & 29,4 \\
\hline Total & $\mathbf{1 7}$ & $\mathbf{1 0 0}$ \\
\hline
\end{tabular}

Sumber: Data Primer, Kuesioner Penelitian, April 2017

Berdasarkan tabel di atas sebagian besar perawat di Ruang Paviliun Maskin RSUD Waluyo Jati Kraksaan Probolinggo peduli perilaku yang berjumlah 12 responden (70,6\%).

Berdasarkan tabel di atas sebagian besar pasien di Space Paviliun Maskin RSUD Waluyo Jati Kraksaan Probolinggo mengatakan tingkat kepuasan pasien dalam asuhan keperawatanpelayanan sangat memuaskan, berjumlah menjadi 27 responden $(81,8 \%)$. Berdasarkan hasil uji statistikAnalisis Wilcoxon Pengaruh KepedulianPerilaku Perawat Terhadap Level KlienKepuasan Dalam Keperawatan Layanan Perawatan DiSpace Pavilion Maskin RSUD WaluyoJati Kraksaan Probolinggo 2014diperoleh nilai nilai 0,000dengan a signifikan tingkat 0,05. Dengan demikian, nilainya lebih kecil dari $(0,05)$ sehingga $\mathrm{HO}$ ditolak dan $\mathrm{H} 1$ diterima. Ini berarti ada Pengaruh Peduli Perilaku Perawat Terhadap Level KlienKepuasan Dalam Keperawatan Layanan Perawatan di Ruang Paviliun Maskin RSUD Waluyo Jati Kraksaan Probolinggo.

Setelah melakukan analisis data dan melihathasil yang diperoleh kemudian akan dibahastentang beberapa hal, yaitu: 1) Merawat perilaku perawat di paviliun maskin kamar RSUD Waluyo Jati Kraksaan Probolinggo. 2) Tingkat klienkepuasan dalam pelayanan asuhan keperawatan dipaviliun publik Maskin ruangan WaluyoRSUD Jati Kraksaan Probolinggo dan 3) Pengaruh perilaku caringperawat terhadap tingkat kepuasan klien dipelayanan asuhan keperawatan di paviliun umum Ruangan Maskin RSUD Waluyo Jati Kraksaan Probolinggo.

\section{Interpretasi dan Pembahasan Hasil}

1. Perilaku Peduli Perawat di Kamar Paviliun Maskin RSUD Waluyo Jati Kraksaan Probolinggo 
Hasil yang diperoleh pada 12 responden(70,6\%) perawat di ruang paviliun Maskin menerapkan perilaku perilaku caring. Berdasarkan data tersebut, dapat dikatakan bahwa sebagian besardari perawat di ruang paviliun umum maskin RSUD Waluyo Jati Kraksaan Probolinggo telah menerapkan perilaku peduli perilaku.

Menurut Watson (2004), yahdikenal dengan Teori Kepedulian Manusia, itu memperkuat Peduli sebagai jenis hubungan dan transaksi yang diperlukan antara pemberidan penerima perawatan untuk meningkatkan danmelindungi pasien sebagai manusia, dengan demikianmempengaruhi kemampuan pasien untuk sembuh. Pada dasarnyaTujuan dari perilaku peduli adalah untukperilaku perawat dalam memberikan asuhan keperawatan pelayanan terdiri dari upaya melindungi, meningkatkan dan memelihara/mengabadikan rasa kemanusiaan dengan membantu orang lain dalam proses menyembuhkan penyakit, penderitaan dan keberadaannyamembantu orang lain untuk meningkatkan pengetahuan dankontrol dengan sentuhan kemanusiaan.

Perilaku peduli adalah inti dari praktik keperawatan karena Caring adalah pendekatan dinamis, di mana perawat bekerja untuklebih meningkatkan kesadaran kepada klien. Berdasarkanhasil penelitian di atas diperolehdengan tingkat pendidikan sudah adabeberapa perawat yang memiliki S1 keperawatanpendidikan yaitu sebanyak 4 responden. Jadi dengan tingkat pendidikan yang lebih tinggi, perawat dapat memberikan contoh perawat lainnya untuk selalu menerapkan perilaku caringperawat. Hal ini juga dapat dipengaruhi oleh jenis kelamin, karena perawat wanita memiliki kepedulian yang lebihperasaan untuk pasien dari perawat laki-laki.

Berdasarkan 10 faktor karative perilaku peduli perawat, yang palingdominan di ruang paviliun Maskin adalahindikator nilai humanistik dan altruistiksistem, sikap hormat, peka terhadapdiri dan orang lain, menciptakan nyamanlingkungan dan pemenuhan kebutuhan dasardari manusia. Meskipun hasil daripenelitian ini menemukan bahwa sebagian besar perawat memilikimenerapkan perilaku perilaku peduli, tetapi adamasih perawat yang belum menerapkan caringperilaku perilaku dalam proses perawatanpelayanan asuhan keperawatan. Dalam keperawatan caring adalahbagian inti yang penting terutama dalam keperawatan berlatih karena perilaku peduli memiliki dasar nilainilai seperti konsep manusia, kesehatan konsep, konsep lingkungan, dan konsep keperawatan. Sehingga perawat diharapkan dapat menerapkan perilaku tersebut dalam memberikan pelayanan prima kepada klien, jadi bahwa klien juga merasa puas dan senang untukmendapatkan pelayanan yang baik. Perilaku perilaku peduliperawat dipengaruhi oleh beberapa faktor, seperti individu, organisasi, dan kepemimpinan, sehingga tidak mudah untuk menerapkannya perilaku tergantung pada kemauan individu itu sendiri.

2. Tingkat Kepuasan Klien dalam Keperawatan Layanan Perawatan di Luar Angkasa Paviliun Maskin RSUD Waluyo Jati Kraksaan Probolinggo

Hasil penelitiannya adalah 27responden $(81,8 \%)$ klien yang dirawat diruang paviliun maskin berkata sangat memuaskan. Berdasarkan data tersebut, sebagian besar pasien di Space Paviliun MaskinRSUD Waluyo Jati Kraksaan Probolinggodikatakan tingkat kepuasan pasien dalampelayanan asuhan keperawatan sangat memuaskan,berjumlah 27 responden $(81,8 \%)$.

Menurut Haffizurrachman, (2004) dikatakan pelayanan kesehatan yang bermutu adalah pelayananberorientasi pada kepuasan setiap penggunapelayanan kesehatan sesuai dengantingkat kepuasan pasien rata-rata.Kepuasan adalah suatu keadaan dimana pasienkebutuhan, keinginan dan harapan dapat dipenuhimelalui layanan yang diberikan. Kepuasanberhubungan dengan kesembuhan pasiendari penyakit atau cedera. Ini lebih terkaitkonsekuensi dari sifat kesehatanlayanan itu sendiri, juga terkait dengan targetdan hasil pelayanan. kepuasan pasiendalam menilai kualitas atau pelayanan yang baik, dan sangat penting untuk kualitas layanan.Ini karena memberikan informasi tentangkeberhasilan penyedia layanan berkualitasdengan nilai dan harapanpasien yang memiliki kewenangan sendiri untukmenetapkan standar kualitas pelayanan yang diinginkan.Kepuasan pasien akan terpenuhi jikaproses pelayanan 
kesehatan kepada pasien dalamsesuai dengan apa yang dirasakan olehpasien. Persepsi ini dipengaruhi olehFaktor subjektivitas yang dapat membuat perbedaanpersepsi atau kesenjangan antara pasien danpenyedia layanan kesehatan.

Pelayanan kesehatan dikatakan memenuhikebutuhan kepuasan pasien jika pelayananasalkan mengikuti standar dan kodeetika yang disepakati dalam suatu profesi, atau dalamkata-kata bahwa jika suatu pelayanan kesehatan telahmengacu pada standar yang ditetapkan olehprofesi yang kompeten dan tidak menyimpang darikode etik yang berlaku untukprofesi. Ukuran yang digunakan untuk menilai seseorangmemikirkan kepuasan yang diperolehnyatermasuk hubungan pelanggan (thehubungan), kenyamanan fasilitas,pilihan, pengetahuan dan keterampilan teknis, efektivitas layanan (Efektifitas) dantindakan pengamanan (safety). Jadi dengan melamar perilaku perilaku caring dalam asuhan keperawatanproses diharapkan klien puas dannyaman dalam mendapatkan pelayanan kesehatan yang berkualitas. Dengan melihat hasil penelitian padatingkat kepuasan klien dalam asuhan keperawatanlayanan di ruang paviliun maskin, pasienmengatakan bahwa pelayanan kesehatan yang diberikan olehperawat di ruang paviliun maskin sangatmemuaskan dan tidak membedabedakanpasien dalam memberikan pelayanan kesehatan, merekatidak berpikir bahwa ada perbedaanantara Klien yang dirawat dengan generalbiaya dan klien yang mendapatkan layanan gratis.

3. Pengaruh Perilaku Caring PerawatTerhadap Tingkat Kepuasan Klien DalamPelayanan Asuhan Keperawatan Di Space Paviliun Maskin RSUD Waluyo Jati KraksaanProbolinggo

Dari hasil penelitian diatasmenunjukkan bahwa ada pengaruh perilaku caringperawat terhadap tingkat kepuasan klien dalamjasa perawatan di paviliun ruangmaskin RSUD Waluyo Jati KraksaanProbolinggo. Diketahui bahwa nilai pnilai 0,000 dengan tingkat signifikansi 0,05.Dengan demikian, nilai $p$ lebih kecil dari $(0,05)$ sehingga Hoditolak dan $\mathrm{H} 1$ diterima.

Menurut Watson (2009) kepedulian Perilaku yang diharapkan dalam keperawatan adalah perilakupengobatan yang didasarkan pada beberapa aspek. Dimembangun perawat yang peduli dapat melaluipengembangan 10 faktor karativeindikator. Dalam pandangan Jean Watsonkeperawatan, laki-laki diyakini sebagai pribadi sebagaiutuh, sebagai diri terintegrasi yang berfungsi penuh.Jean Watson mendefinisikan kesehatan sebagai sesuatu yang utuh dankondisi yang harmonis antara tubuh, pikiran, dan jiwa, berkorespondensi ini dengan tingkatkesesuaian antara persepsi diri dandiri yang diwujudkan.

Azwar (2006) mengatakan bahwa pelayanan kesehatan dikatakan memenuhi kebutuhankepuasan pasien ketika pelayanan asalkan memiliki ukuran yang digunakan untuk menilaipemikiran seseorang tentang kepuasan yang dia rasakandiperoleh, termasuk hubungan daripelanggan (hubungan), kenyamanan fasilitas, Membuat pilihan, pengetahuan dan keterampilan teknis (pengetahuan ilmiah dan keterampilan teknis), efektivitas (efektivitas) dan tindakan pengamanan (safety).

Menurut Azwar, (2006) mengatakan kebutuhan suatu pelayanan kesehatan dinyatakan sebagaipelayanan yang berkualitas dan dapat memberikan kepuasan kepadapenerima jika layanan yang diusulkan atauditentukan, termasuk penilaian terhadapkepuasan pasien tentang kesehatan yang tersediapelayanan, Kesehatan yang sesuai, berkesinambunganpelayanan, pelayanan kesehatan yang dapat diterima, aksesibilitas yang dapat diakses, kesehatan yang terjangkau perawatan, pelayanan kesehatan yang efisien dan kualitas pelayanan kesehatan. Untuk melaksanakan pelayanan kesehatan yang memenuhi semua persyaratan layanan adalahtidak semudah yang diharapkan, jadi untuk mengatasinya menerapkan prinsip kepuasan yang digabungkan secara selektif dan efektif, dalamarti menerapkan kelompok pertamadimensi kepuasan dilakukan secara optimal, sementara beberapa dimensi kelompok kedua adalahdilakukan secara selektif Sesuai dengan kebutuhan dan kemampuan.

Kepuasan tidak hanya dipengaruhi olehfaktor penyedia saja, tetapi juga dipengaruhi faktor dari luar dan dari dalam diri pasien. Faktor internal termasuk sumber daya, pendidikan, pengetahuan dansikap. Faktor eksternal meliputi budaya,sosial 
ekonomi, keluarga dan situasi yang dihadapi. Penilaian kualitas layanan dikaitkandengan kepuasan pasien dengan berfokus padaaspek fungsional dari proses layanan. Kemengukur tingkat kepuasan dapatdinilai dengan beberapa indikator, salah satunya adalah:

Tangible adalah manifestasi langsung fasilitas fisik, termasuk kedalaman peralatan yang digunakan, kondisifasilitas, kondisi sumber daya manusia.

Keandalan adalah layanan yangdisajikan segera dan memuaskan dansebuah aspek - aspek keandalan layanansistem yang disediakan oleh penyedia layanan yang termasuk kesesuaian penyampaian layanan dengan rencana tersebut, kepedulian perusahaan terhadapmasalah yang dialami pasien,keandalan penyampaian Iayanan dariawal, ketepatan waktu layananSesuai dengan janji yang diberikan dalamketepatan penanganan.

Ketanggapan (responsibility) adalah keinginan untuk membantu dan memberikan pelayanan yangkonsumen butuhkan. Ini termasuk kejelasaninformasi tentang waktu pengiriman layanan, ketepatan dan kecepatan dalam pelayanan administrasi,kesediaan karyawan untuk membantu pelanggan, waktu karyawan dalam menanggapi pasienpermintaan dengan cepat.

Assurance (jaminan) adalah jaminan bahwa layanan yang ditawarkan memberikan keamananjaminan yang meliputi kemampuan manusiasumber daya, rasa aman selama bertransaksidengan karyawan, kesabaran karyawan, dukungankepemimpinan staf.

Empati (empati) berkaitan dengan memberikan perhatian penuh kepada konsumen bahwameliputi perhatian kepada konsumen, pribadi,perhatian staf kepada konsumen,pemahaman tentang kebutuhan konsumen, perhatian padakepentingan konsumen, kesesuaianwaktu pelayanan dengan kebutuhan konsumen.

Dengan menerapkan perilaku caring perawat perilaku diharapkan klien akan merasa puas terhadap pelayanan asuhan keperawatan yang diberikan kepada klien. Jadi agar pelayanan kesehatan dapat memberikan pelayanan yang primapelayanan sesuai dengan kode etikprofesi kesehatan, harapan pemerintah,instansi terkait dan masyarakat ditertentu. Meskipun masih banyakfaktor yang mempengaruhi perilaku peduliperawat dan tingkat kepuasan seseorang,karena manusia itu unik karenaberbeda dari satu manusia ke yang lain.

\section{Kesimpulan}

1. Perilaku Peduli Perawat di Ruang Angkasa Paviliun Maskin RSUD Waluyo JatiKraksaan Probolinggo kebanyakan peduliperilaku yang berjumlah 12responden (70,6\%).

2. Tingkat kepuasan klien dalampelayanan asuhan keperawatan di Room PaviliunMaskin RSUD Waluyo Jati KraksaanProbolinggo sebagian besar sangat memuaskan yang manaberjumlah 27 responden $(81,8 \%)$.

3. Ada pengaruh perilaku caring terhadap perawat terhadap tingkat kepuasan klien dipelayanan asuhan keperawatan di Room of Paviliun Maskin RSUD Waluyo Jati Kraksaan Probolinggo Diperoleh $\mathrm{p}$ value 0,000 dengan0,05 sehingga $\mathrm{H} 1$ diterima.

\section{Daftar Pustaka}

Alimul, H, Aziz. (2008). Riset Keperawatan Dan Teknik Penulisan ILmiah, Jakarta: Salemba Medika.

Anjaswarni,T.(2002). Analisis tingkat kepuasan klien terhadap perilaku caring perawat di ruang rawat instalasi rawat inap RSUD Saiful Anwar Malang. Jakarta: FIKUI.

Arikunto, (2005). Prosedur Penelitian Suatu Pendekatan Praktek, Jakarta: Ghalia Indonesia.

Christerisen, P.J \& Kenney J. (2006). Nursing process aplication of conceptual models, 4th edition. St. Louis: The C.V. Mosby Company

George, Julia B. (2004). Nursing theories: the base for professional nursing practice, 4th edition. Connecticut: Apleton \& Lange

Ismar,A. (2002). Perilaku caring perawat dan hubungannya dengan kepuasan klien di instalasi rawat inap bedah dewasa Rumah Sakit dokter Mohammad Hoesin. Jakarta. FIKUI.

Kotler, (2003). Manajemen Pemasaran, Edisi kesebelas,Jakarta, PT. Prenhallindo.

Kozier, B., Erb, G., Berman, A. J., \& Snyder. (2004). Fundamentals of Nursing: Concepts, Process, and Practice. 7th Ed. New Jersey: Pearson Education, Inc. 
Natsir, J. E. (2008). Kinerja Perawat Dalam Melaksanakan Asuhan Keperawatan Di Rumah Sakit Dan Faktor Yang Mempengaruhi. diakses tanggal 1 Juli 2013

Nursalam. (2008). Konsep dan Penerapan Metodologi Penelitian IImu Keperawatan, Jakarta: Salemba Medika.

Nursalam. (2008). Proses dan Dokumentasi Keperawatan : Konsep dan Praktek. Salemba Medika. Jakarta

Nuralam dan Siti Pariani. (2008). Metodologi Riset Keperawatan, Jakarta: Seagung Seto.

Potter, P. A. \& Perry A. G. (2005). Fundamentals of Nursing : Concepts, Process, and Practice. 6th Ed. St. Luois, MI : Elsevier Mosby.

Potter \& Perry, (2005). Fundamental of Nursing Fundamental keperawatan, Buku 1 Edisi 7, Editor Dripa sjabana, Salemba Medika, Jakarta.

Rahayu,S.(2001).Faktor-faktor yang berhubungan dengan sikap caring yang dipersepsikan oleh perawat pelaksana diruang rawat inap RSUP Persahabatan. Jakarta:FIKUI
Rubenfeld,M.G.\&Barbara,K.S.(1999).Cri tical thingking in nursing: An Interactive Approach. (2nd edition). Philadelphia: Lippincott.

Setiadi. (2007). Metodologi Penelitian IImu Keperawatan. Graha Ilmu, Yogyakarta

Supranto. (2001). Pengukuran Tingkat Kepuasan Pelanggan Termasuk Analisis Tingkat Kepentingan dan Kinerja. Usahawan No. 05, Th. XXVI.

Supranto (2011). Menjaga Mutu Pelayanan Di Rumah Sakit (Quality Assurance); Persi, Jakarta.

Swanson, K. M. (2004). Nursing as informed caring for the well-being of other image: The Journal Of Nursing Scholarship. 25(4). 352-357).

Vance,T.(2007).Caringand the professional practice of nursing. Diakses pada tanggal 01 Juli 2013. Dari http://www.proguest. com/pqdweb.

Watson,J. (2004). Caring Science as Sacred Science. Philadelphia: FA Davis Company.

Watson,J. (2006). Assesing and measuring caring in nursing and health sciences: FA Davis Company. 